\title{
Brazilian Journal of Mother and Child Health - Year 20
}

It is with great satisfaction to inform that the Brazilian Journal of Mother and Child Health (BJMCH) is celebrating its 20 years of existence and for this very reason it brings us a feeling of great joy. However, this is occurring at a time of such a terrible pandemic upon us, forcing us to also say that it is an anniversary mixed with joy and sadness. The joy is for our achievements and growth, butthe sorrow is because we are living at a time of enormous anguish, the uncertainty and suffering.

Where does the joy come from? Certainly, from the memory of our distant beginning, facing natural difficulties at the beginning of a great project - editing a scientific journal -starting from difficult conditions of that time. Fortunately, however, we were able to meet the demands and responsibilities that, by the way, increased a lot over time. In any case, we published articles that fulfilled our expectations in terms of quality and thematic approach. Articles such as Musgrove's "What is the minimum a doctor should know about health economics"1 or Ebrahim's "Poli eradication, and after..."2, or Maciel Filho and Araújo Jr. "Discussing community participation in health: an approach from the Brazilian experience"3 or even Batista Filho's "“Anthropometric evaluation on nutritional status of pregnant women: retrospective and prospective view"4 or "Anemia control in Brazil"5, these were all relevant subjects in our first years and are good examples of that period and our history. We grew steadily in the number of publications, receiving from fifty to sixty manuscripts, we now receive more than 500 annually, and with a rejection rate of more than $90 \%$, which is not little. Indexed in 15 international databases including SciELO, EBSCO and SCOPUS, we are content with our editorial performance. We would like to take this opportunity to thank our reviewers and especially our writers, which have given us so much confidence. Indeed, a scientific journal is not an isolated entity and does not exist without its editors, its contributors, and its readership. That is why our journal has a great role and responsibility in the health community and, in the current health situation, it has not shied away from fulfilling them. That is why, we have just pu-blished a supplementary issue on COVID-19, ${ }^{6}$ and another issue is being edited. It is, at least, a sample of our intention to participate in the effort of the world of scientific periodism, facing such a serious threat to survive through it all. In fact, at this moment, the idea of communicating as much as science can (and does) is indispensable. For all these reasons, the task of disseminating what science has been accomplishing in the battle against such a powerful and destructive enemy is our beacon. We are witnessing all over the world a density of publications on the same theme never seen before. Therefore, we are inserted in this true mainstream of life sciences. When necessary, science may run further, it can win the fight, and it is already winning! What's more, it has rarely shown itself to be as agile and competent as it is now. It is not without reason that its ability to produce vaccines, not just one, but several of them, for one disease and in such a short time has been so well revealed. Science, when well applied, always gives us hope. Never a step back! In fact,all this capability - through its workers in microbiology, epidemiology, and public health, as well as those who apply it every day on the front lines seeking to relieve and save lives while risking their own - must be honored here. Let us recognize that science exists to promote life.

Yes, these victories should be recognized, and they make us thrilled. The power of science, and in our particular case, the history of RBSMI, directly involves us and makes us excited. But we can never forget this mo- 
ment of pain and suffering, a lethal emergency, if you can put it that way. This is why our happiness is not complete. Saddened, like everyone else, by the loss of so many human beings, we are, at the same time, experiencing a moment of mourning.

Unfortunately!

\section{References}

1. Musgrove P. What is the minimum a doctor should know about health economics?. Rev Bras Saúde Mater Infant. 2001; 1 (2): 103-9.

2. Ebrahim GJ. Poli eradication, and after... Rev Bras Saúde Mater Infant. 2002; 1 (2): 189-91.

3. Maciel Filho R, Araujo Jr. JLC. Discussing community participation in health: an approach from the Brazilian experience. Rev Bras Saúde Mater Infant. 2002; 2 (2): 91-103.

4. Coelho KS, Souza AI, Batista Filho M. Avaliação antropométrica do estado nutricional da gestante: visão retrospectiva e prospectiva Rev Bras Saúde Mater Infant. 2002; 2 (1): 57-61.

5. Batista Filho M. O controle das anemias no Brasil. Rev Bras Saúde Mater Infant. 2002; 4 (2): 121-3.

6. Rev Bras Saúde Mater Infant. 2021; 21 (Supl. 1) Disponível em: https://www.scielo.br/scielo.php?script=sci_issuetoc\&pid=1519$382920210001 \& \operatorname{lng}=$ en\&nrm $=$ iso

José Eulálio Cabral Filho 1

(iD https://orcid.org/0000-0001-9121-9910

1 Editor in Chief of the Brazilian Journal of Mother and Child Health. Rua dos Coelhos, 300. Boa Vista. Recife, PE, Brazil. 